
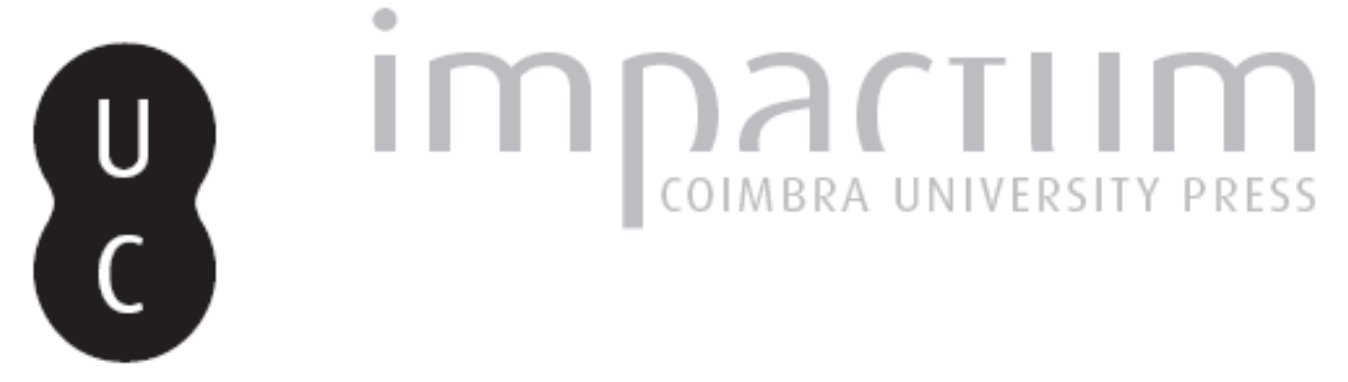

\title{
Monetary poverty, material deprivation and consistent poverty in Portugal
}

Autor(es): $\quad$ Rodrigues, Carlos Farinha; Andrade, Isabel

Publicado por: Faculdade de Economia da Universidade de Coimbra

URL persistente:

URI:http://hdl.handle.net/10316.2/25205

DOI:

DOI:http://dx.doi.org/10.14195/2183-203X_35_2

Accessed : $\quad$ 26-Apr-2023 10:54:23

A navegação consulta e descarregamento dos títulos inseridos nas Bibliotecas Digitais UC Digitalis, UC Pombalina e UC Impactum, pressupõem a aceitação plena e sem reservas dos Termos e Condições de Uso destas Bibliotecas Digitais, disponíveis em https://digitalis.uc.pt/pt-pt/termos.

Conforme exposto nos referidos Termos e Condições de Uso, o descarregamento de títulos de acesso restrito requer uma licença válida de autorização devendo o utilizador aceder ao(s) documento(s) a partir de um endereço de IP da instituição detentora da supramencionada licença.

Ao utilizador é apenas permitido o descarregamento para uso pessoal, pelo que o emprego do(s) título(s) descarregado(s) para outro fim, designadamente comercial, carece de autorização do respetivo autor ou editor da obra.

Na medida em que todas as obras da UC Digitalis se encontram protegidas pelo Código do Direito de Autor e Direitos Conexos e demais legislação aplicável, toda a cópia, parcial ou total, deste documento, nos casos em que é legalmente admitida, deverá conter ou fazer-se acompanhar por este aviso.

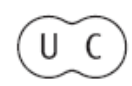




\section{N॰TASEC}

\section{Recent debates on poverty and inequality}

A Special issue in memory of Leonor Vasconcelos Ferreira (1960-2008)

AURORA TEIXEIRA/THE SCIENTIFIC CONTRIBUTION OF LEONOR VASCONCELOS FERREIRA SANDRA SILVA/

PEDRO TEIXEIRA

CARLOS FARINHA RODRIGUES/ ISABEL ANDRADE

MONETARY POVERTY, MATERIAL DEPRIVATION AND CONSISTENT POVERTY IN PORTUGAL

JOANA AFONSO/ ISABEL MOTA/

MICRO CREDIT AND TERRITORY: PORTUGAL AS A CASE STUDY SANDRA SILVA

MARIA CIDÁLIA QUEIROZ/ MARIELLE GROS
SOCIAL INSERTION INCOME: THE CONTRIBUTION OF THE ASSOCIATION QUALIFICAR PARA INCLUIR 

Poverty in Portugáa*

Carlos Farinha Rodrigues / Isabel Andrade ISEG, UTL; CEMAPRE/ ISEG, UTL

Neste artigo utilizamos os dados do Inquérito às Condições de Vida e Rendimento (EU-SILC) para definir uma medida de pobreza consistente para Portugal. É consensual que ser pobre não se reduz a não ter rendimentos monetários suficientes. A pobreza inclui também a falta de acesso aos recursos necessários para desfrutar de um nível de vida de qualidade mínima e participar activamente na sociedade a que pertencemos. A coexistência de privação material e pobreza monetária leva à definição do conceito de pobreza consistente. A avaliação da privação material e a identificação das famílias e indivíduos que vivem em situações de pobreza consistente podem tornar-se elementos fundamentais da estratégia nacional anti-pobreza e instrumentos cruciais na definição dos grupos alvo da política social.
Dans cet article nous utilisons le component Portugais de L'enquête EU-SILC pour développer une mesure de la pauvreté consistante au Portugal. Il est généralement accepté qu'être pauvre n'est pas limité a l'absence de ressources monétaires suffisants. Pauvreté signifie aussi n'avoir pas l'accès aux ressources nécessaires pour jouir d'un niveau de vie de qualité minimum et engager à la vie en société. La coexistence de privation matérielle et pauvreté monétaire résulte dans le concept de pauvreté consistante. L'évaluation de la privation matérielle et l'identification des ménages et individus qui vivent en situation de pauvreté consistante peuvent devenir un élément essentiel de la stratégie nationale antipauvreté et un instrument crucial dans la définition des groupes plus vulnérables de la population.

In this paper we use the Portuguese component of the European Union Statistics on Income and Living Conditions (EU-SILC) to develop a measure of consistent poverty in Portugal. It is widely agreed that being poor does not simply mean not having enough monetary resources. It also reflects a lack of access to the resources required to enjoy a minimum standard of living and participation in the society one belongs to. The coexistence of material deprivation and monetary poverty leads to the concept of consistent poverty. The assessment of material deprivation and the identification of the households and individuals living in consistent poverty could become essential parts of the national anti-poverty strategy and crucial instruments in the definition of the target groups in social policy. 


\title{
1. Introduction
}

The use of both income and deprivation criteria to identify the most vulnerable sectors of the society has become increasingly popular in both the poverty and social policy literature. The adoption by the Indicators Sub-Group of the Social Protection Committee of the European Union in 2009 of a new broader indicator of material deprivation also contributed to the recent increase in the discussion on multidimensional measures of poverty, deprivation and social exclusion.

This broader definition of poverty as the lack of both monetary and non-monetary resources became more pertinent after Ringen's (1988) criticism of exclusively using income to identify poverty. This criticism was clearly inspired by Townsend's (1979) definition of poverty:

\begin{abstract}
"Individuals, families and groups in the population can be said to be in poverty when they lack the resources to obtain the type of diet, participate in the activities and have the living conditions and amenities which are customary, or at least widely encouraged, or approved, in the societies to which they belong. Their resources are so seriously below those commanded by the average individual that they are, in effect, excluded from ordinary living patterns, customs and activities (p. 31)».
\end{abstract}

At European level, the limitations of a monetary-only definition of poverty gathered a new emphasis with the enlargement of the EU into Eastern Europe and consequent increase in the heterogeneity of the standards of living of the enlarged EU population.

In this paper we analyse the implication of the simultaneous use of monetary poverty and material deprivation indicators to characterise the most vulnerable individuals and households in Portugal. We use the micro-data of the Portuguese component of the 2008 wave of the EU-SILC, made available by INE-Statistical Portugal, to develop measures of monetary poverty and material deprivation for Portugal ${ }^{1}$. Their joint usage will achieve a much more thorough and detailed analysis of the multiple dimensions of poverty and will lead to a more efficient design and implementation of policies to fight poverty.

The first aim of this paper is to examine the methodological issues concerning the construction of a measure of material deprivation using the multiple material deprivation indicators available. The second aim is to characterise material deprivation in Portugal and to identify the households which suffer from higher deprivation levels. The relationship between the national level of monetary poverty and the extent and depth of material deprivation experienced by the population is also analysed. Finally, the identification of the sectors of the population which are consistently poor will allow a detailed analysis of multidimensional poverty in Portugal and contribute to highlight the relationship between income poverty and material deprivation.

\section{Poverty and Material Deprivation}

Studies of poverty generally concentrate their efforts on the description of the population that is poor, how many are income poor (poverty incidence) and how poor they are (poverty intensity) using measures of the monetary dimension of poverty. In $2007,18.5 \%$ of the Portuguese were poor, i.e., the annual disposable equivalent income of about 1.97 million people was below $€ 4886$, the poverty line ${ }^{2}$ in that year (see Table 1 ). The poverty intensity ${ }^{3}$ was equal to $23.2 \%$.

1. We acknowledge the INE-Statistical Portugal for allowing us access to the data (Protocol INE/MCES, process 237).

2. The poverty line is defined as $60 \%$ of the median of the equivalent disposable income.

3. The concept of «poverty incidence» used in this paper is equivalent to Eurostat's «people in risk of poverty». 
Table 1 - Monetary Poverty

\begin{tabular}{lccc} 
& \multirow{2}{*}{ Value } & \multicolumn{2}{c}{ 95\% Confidence Interval } \\
\cline { 3 - 4 } & & Lower & Upper \\
\hline Poverty Incidence & 18.5 & 16.7 & 20.3 \\
Poverty Intensity & $(0.9)$ & & \\
& 23.2 & 20.8 & 25.6 \\
& $(1.2)$ & &
\end{tabular}

Notes: Standard errors in parenthesis. Source: 2008 Portuguese EU-SILC

However, this analysis can and should be furthered by investigating the material dimension of poverty, i.e., the inability to attain certain basic standards of living and consumption. It is widely agreed that being poor does not simply mean not having enough monetary resources: it also reflects a lack of access to the resources required to enjoy a minimum standard of living and participation in the society one belongs to. If individuals are both poor and materially deprived they are defined as consistently poor.

In order to implement these concepts, the EU has defined nine indicators of material deprivation. They include a wide range of items that are listed in detail in the first column of Table $2^{4}$. The $2^{\text {nd }}$ column of the table gives the percentages of 'enforced lack', i.e., the percentages of individuals that would have like to possess each item, but could not afford it, and were therefore deprived of it. The first EU agreed measure of material deprivation is defined as the enforced lack of at least (any) three of the nine items, and therefore is a measure of the deprivation incidence. The second is a measure of its intensity, and is defined as the mean of the number of items the deprived individuals are deprived of. ${ }^{5}$

Table 2 - Deprivation Indicators

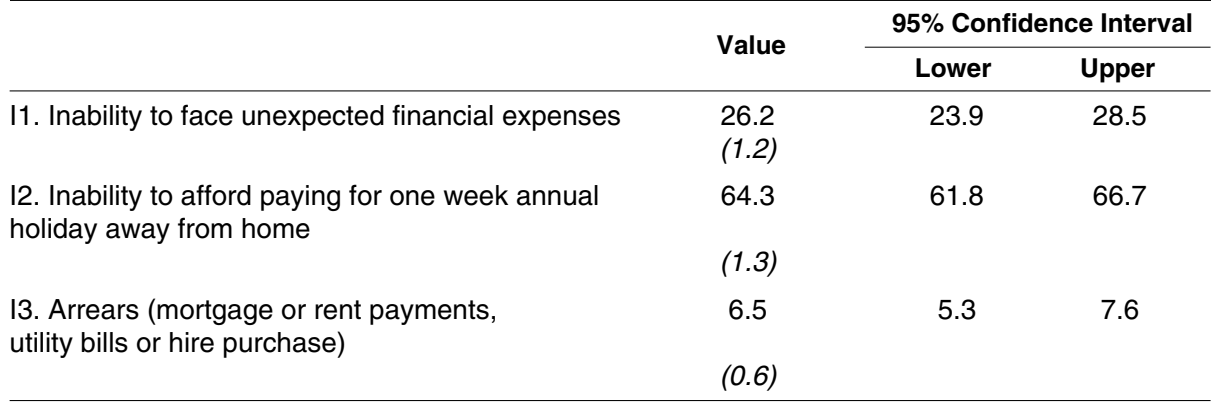

«Poverty intensity» is defined as Eurostat's «relative at risk-of-poverty gap», the difference between the median income of those below the poverty line and the value of the poverty line itself, expressed in relation to the poverty line. The usage of the Eurostat poverty indicators, instead of the more traditional indicators suggested by Foster, Greer e Thorbeck (Foster et al. (1984)), is justified by the objective of comparability with the "official» indicators used at European level. For a study of Portuguese poverty using the Foster, Greer e Thorbeck indices see Rodrigues,C.F. (2010).

4. These indicators distinguish between households who do not own items 6 to 9 because of a lack of financial capacity from those who do not own them because of a lack of interest or necessity.

5. See, for example, Guio, Fusco and Marlier (2009) and Guio (2009) for a discussion of these measures and choice of threshold ( 3 or more items). 
Table 2 - Deprivation Indicators (cont.)

\begin{tabular}{lccc} 
& \multirow{2}{*}{ Value } & \multicolumn{2}{c}{$95 \%$ Confidence Interval } \\
\cline { 3 - 4 } & & Lower & Upper \\
\hline 14. Inability to afford a meal with meat, & 4.0 & 2.8 & 5.3 \\
chicken or fish every second day & $(0.6)$ & & \\
15. Inability to keep home adequately warm & 34.9 & 31.9 & 37.9 \\
16. Enforced lack of a washing machine & $(1.5)$ & & \\
17. Enforced lack of a colour TV & 2.5 & 1.9 & 3.0 \\
18. Enforced lack of a telephone & $(0.3)$ & & \\
& 0.5 & 0.2 & 0.7 \\
19. Enforced lack of a personal car & $(0.1)$ & & \\
& 4.5 & 3.5 & 5.5 \\
\hline
\end{tabular}

Notes: Standard errors in parenthesis. Source: 2008 Portuguese EU-SILC

According to the EU-SILC 2008 23.0\% of the Portuguese, just over 2.4 million people, were materially deprived (Table 3). The intensity of their deprivation, i.e., the average number of items they were deprived of, was 3.6. It should be noted that $30.3 \%$ of the whole population were not deprived of any item at all.

Table 3 - Material Deprivation

\begin{tabular}{cccc} 
& Value & \multicolumn{2}{c}{$95 \%$ Confidence Interval } \\
\cline { 3 - 4 } & & Lower & Upper \\
\hline Deprivation Incidence & $\begin{array}{c}23.0 \\
(1.1)\end{array}$ & 20.8 & 25.1 \\
Deprivation Intensity & 3.6 & 3.6 & 3.7 \\
& $(0.0)$ & & \\
\hline
\end{tabular}

Notes: Standard errors in parenthesis. Source: 2008 Portuguese EU-SILC

Crossing monetary poverty and material deprivation in Table 4 gives a much more detailed picture of the standards of living of the Portuguese: 7.1 million Portuguese $(67.0 \%$ of the population) were 'neither poor nor deprived', 1.5 million (14.5\%) were 'not poor and deprived', 1 million (10.0\%) were 'poor and not deprived', and 900 thousand ( $8.5 \%$ ) were 'both poor and deprived'. The latter are the consistent poor, the most vulnerable group of the population ${ }^{6}$.

6. The calculated percentage of poor and deprived individuals ( $8.5 \%)$ is very close to that of persistently poor individuals calculated by Eurostat, using the longitudinal data of EU-SILC. The connection between consistent poverty calculated each year and persistent poverty computed longitudinally is clearly one of the avenues of future development of our research. 


\begin{tabular}{lccc} 
& Not Deprived & Deprived & Total \\
\hline Not Poor & 67.0 & 14.5 & 81.5 \\
& $(1.2)$ & $(0.8)$ & $(0.9)$ \\
Poor & 10.0 & 8.5 & 18.5 \\
& $(0.7)$ & $(0.6)$ & $(0.9)$ \\
\hline \multirow{2}{*}{ Total } & 77.0 & 23.0 & 100.0 \\
& $(1.1)$ & $(1.1)$ & \\
\hline
\end{tabular}

Notes: Standard errors in parenthesis. Source: 2008 Portuguese EU-SILC

The recent evolution of these measures in Portugal and the EU27 is summarised in Table 5. The Portuguese were poorer and more intensely poorer than the average EU27 citizen, though their situation has been improving. They were also more deprived than the EU average.

\begin{tabular}{cccccc} 
Table 5 - Monetary poverty versus Material Deprivation & & & & \\
& & $\mathbf{2 0 0 5}$ & $\mathbf{2 0 0 6}$ & $\mathbf{2 0 0 7}$ & $\mathbf{2 0 0 8}$ \\
\hline Poverty Incidence & PT & 19.4 & 18.5 & 18.1 & 18.5 \\
& EU27 & 15.9 & 16.1 & 16.7 & 16.5 \\
Poverty Intensity & PT & 26.0 & 23.5 & 24.3 & 23.2 \\
& EU27 & 22.4 & 22.5 & 23.0 & 21.9 \\
\hline Deprivation Incidence & PT & 21.2 & 20.0 & 22.4 & 23.0 \\
& EU27 & 17.4 & 17.4 & 17.8 & 17.4 \\
Deprivation Intensity & PT & 3.7 & 3.7 & 3.7 & 3.6 \\
& EU27 & 3.8 & 3.8 & 3.9 & 3.8
\end{tabular}

Source: Eurostat EU-SILC - Values for poverty indicators based on data of previous year.

Another way of looking at the results in Table 4 is that $45.8 \%$ of the Portuguese poor were also materially deprived (consistent poor). However, it should be pointed out that most $(63.0 \%)$ of the deprived were not poor, and that most $(54.2 \%)$ of the poor were not deprived. This perhaps surprising result needs to be discussed in more detail.

This result is put in evidence in Table 6 where the two deprivation measures ${ }^{7}$ are reported by equivalent income decile. Whereas poverty is situated by construction in the $1^{\text {st }}$ and $2^{\text {nd }}$ deciles of the distribution, material deprivation is spread throughout the income deciles. Only just over half $(50.8 \%)$ of the poorest individuals were deprived, with an average deprivation of 2.7 items. It is the highest value of deprivation index by decile, but still below the threshold $3+$ items. On the opposite end of the distribution, $1.2 \%$ of the wealthiest individuals $\left(10^{\text {th }}\right.$ decile) considered themselves deprived of $3+$ items, and were therefore materially deprived. 
The index of deprivation of the whole population (deprived or not) was equal to 1.5 , meaning that, on average, each Portuguese was deprived of 1.5 items, and fell consistently through the deciles. Nevertheless, the incidence of the deprivation was still quite significant in the $6^{\text {th }}$ and $7^{\text {th }}$ deciles (about $15 \%$ of the individuals in these deciles were deprived).

\section{Table 6 - Material Deprivation by equivalent income decile}

\section{Deprivation Incidence Deprivation Index}

\begin{tabular}{lcc}
\hline $1^{\text {st }}$ decile & 50.8 & 2.7 \\
$2^{\text {nd }}$ decile & 39.6 & 2.3 \\
$3^{\text {rd }}$ decile & 41.2 & 2.2 \\
$4^{\text {rd }}$ decile & 29.9 & 1.9 \\
$5^{\text {th }}$ decile & 22.6 & 1.7 \\
$6^{\text {th }}$ decile & 14.7 & 1.4 \\
$7^{\text {th }}$ decile & 14.4 & 1.3 \\
$8^{\text {th }}$ decile & 9.7 & 1.0 \\
$9^{\text {th }}$ decile & 5.7 & 0.6 \\
$1^{\text {th }}$ decile & 1.2 & 0.2 \\
\hline Total & 23.0 & 1.5 \\
\hline
\end{tabular}

Source: 2008 Portuguese EU-SILC

It is possible to analyse the deprivation levels by item (Table 7). The most deprived item was 'I2' (hereafter denoted 'holiday'): $64.3 \%$ of the Portuguese answered they could not afford a week holiday away from home (57.9\% of the Not Poor and $92.1 \%$ of the Poor). It was followed by ' 15 ' (hereafter denoted 'homewarm') with 34.9\%, and 'I1' (hereafter 'expenses') with 26.2\%. By far, in all groups and in the same relative order, these 3 items were the ones most Portuguese were deprived of ${ }^{8}$. The (distant) fourth placed item was ' 19 ' (hereafter 'car') of which $9.4 \%$ of the Portuguese were deprived of. The least deprived items were (in increasing \% order)

\section{Table 7 - Deprivation Indicators (Poor versus Not Poor population)}

11. Inability to face unexpected financial expenses Not Poor Poor All

12. Inability to afford paying for one week annual holiday away from home

$21.5 \quad 46.7 \quad 26.2$

13. Arrears (mortgage or rent payments, utility bills or hire purchase) $57.9 \quad 92.1 \quad 64.3$

14. Inability to afford a meal with meat, chicken or fish every second day

I5. Inability to keep home adequately warm

$2.8 \quad 9.8 \quad 4.0$

16. Enforced lack of a washing machine

17. Enforced lack of a colour TV

$\begin{array}{lll}1.4 & 7.0 \quad 2.5\end{array}$

18. Enforced lack of a telephone

$0.4 \quad 0.8 \quad 0.5$

19. Enforced lack of a personal car

$3.6 \quad 8.5 \quad 4.5$

$\begin{array}{lll}7.0 & 20.2 & 9.4\end{array}$

Source: 2008 Portuguese EU-SILC 
'I7' (hereafter 'TV') with $0.5 \%$, 'I6' (hereafter 'washingmachine') with $2.5 \%$, 'I4' (hereafter 'meal') with $4.0 \%$, 'I8' (hereafter 'phone') with $4.5 \%$, and 'I3' (hereafter 'arrears') with $6.5 \%$. The only difference in the relative ordering of the items is that the poor were more deprived of 'meal' than of 'phone', unlike the rest of the population.

The poor were much more likely than the not poor to be deprived of washingmachine ( 5 times more), meal (3.5), car (2.9), and arrears (2.7). The smallest difference was actually recorded in the most deprived item, holiday (1.6), reflecting its widespread lack. A staggering $92.1 \%$ of the poor could not afford it.

It is possible to study poverty and material deprivation in more detail by analysing its impact on different socio-economic characteristics of the population, which is the aim of the next section.

\section{Poverty and Material Deprivation by categories of the population}

The EU-SILC data allows for a detailed analysis of the different socio-economic categories of the Portuguese population. Four of these categories were retained in this study: age group, household type, economic status (individuals older than 16) and degree of urbanisation.

\section{Table 8 - Monetary poverty versus Material Deprivation}

\begin{tabular}{|c|c|c|c|c|}
\hline & $\begin{array}{l}\text { Poverty } \\
\text { Incidence }\end{array}$ & $\begin{array}{l}\text { Poverty } \\
\text { Intensity }\end{array}$ & $\begin{array}{l}\text { Deprivation } \\
\text { Incidence }\end{array}$ & $\begin{array}{l}\text { Deprivation } \\
\text { Intensity }\end{array}$ \\
\hline \multicolumn{5}{|l|}{ Gender } \\
\hline Men & 17.9 & 22.5 & 22.3 & 3.7 \\
\hline Women & 19.1 & 23.6 & 23.6 & 3.6 \\
\hline \multicolumn{5}{|l|}{ Age Group } \\
\hline Age $<=17$ & 22.8 & 26.2 & 24.8 & 3.7 \\
\hline $18<=$ Age $<=64$ & 16.3 & 23.6 & 21.1 & 3.6 \\
\hline Age $>=65$ & 22.3 & 17.7 & 27.8 & 3.6 \\
\hline \multicolumn{5}{|l|}{ Household Type } \\
\hline Single - age $<65$ & 25.0 & 37.0 & 35.4 & 4.2 \\
\hline Single - age $>=65$ & 34.5 & 26.9 & 37.9 & 3.6 \\
\hline Two adults younger than 65 years & 16.5 & 23.6 & 20.0 & 3.7 \\
\hline $\begin{array}{l}\text { Two adults, at least one } \\
\text { aged } 65 \text { years and over }\end{array}$ & 21.7 & 15.7 & 26.7 & 3.7 \\
\hline Three or more adults & 7.6 & 18.8 & 18.9 & 3.4 \\
\hline Single parent with dependent children & 38.9 & 31.3 & 46.9 & 3.8 \\
\hline Two adults with one dependent child & 17.0 & 18.7 & 20.3 & 3.6 \\
\hline Two adults with two dependent children & 20.6 & 24.8 & 16.7 & 3.7 \\
\hline Two adults with three + dependent children & 31.9 & 36.4 & 35.8 & 3.9 \\
\hline Other Households with dependent children & 18.2 & 22.9 & 23.0 & 3.6 \\
\hline
\end{tabular}




\begin{tabular}{lcccc}
\hline Table 8 - Monetary poverty versus Material Deprivation (cont.) & $\begin{array}{c}\text { Poverty } \\
\text { Incidence }\end{array}$ & $\begin{array}{c}\text { Poverty } \\
\text { Intensity }\end{array}$ & $\begin{array}{c}\text { Deprivation } \\
\text { Incidence }\end{array}$ & $\begin{array}{c}\text { Deprivation } \\
\text { Intensity }\end{array}$ \\
\hline $\begin{array}{l}\text { Economic Status } \\
\quad\end{array}$ & & & & \\
$\quad$ Working & 12.3 & 21.7 & 17.8 & 3.6 \\
$\quad$ Unemployed & 29.3 & 27.5 & 38.4 & 3.9 \\
$\quad$ In retirement & 19.7 & 18.1 & 26.4 & 3.6 \\
$\quad$ Other inactive person & 29.5 & 25.5 & 28.7 & 3.7 \\
\hline Degree of Urbanisation & & & & \\
$\quad$ densely populated area & 13.4 & 23.4 & 24.9 & 3.6 \\
$\quad$ intermediate area & 22.2 & 22.4 & 22.8 & 3.7 \\
$\quad$ thinly populated area & 23.4 & 23.5 & 19.5 & 3.6 \\
\hline Total & 18.5 & 23.2 & 23.0 & 3.6 \\
\hline
\end{tabular}

Source: 2008 Portuguese EU-SILC.

They give the analysis a sufficient degree of detail to identify the sectors of the population which were in a more vulnerable situation. The incidence and intensity of both poverty and deprivation by categories are reported in Table 8 and they prove to be important factors to understand how they both affected the Portuguese population.

Women recorded higher poverty and deprivation rates than men and slightly higher than the global average. By age group, the young and the elderly recorded higher poverty and deprivation rates than the rest of the population: $22.8 \%$ of the children (aged 17 and under) and $22.3 \%$ of the elderly (people aged 65 and above) were poor. The poverty intensity for the children (26.2\%) was higher than that for those between 18 and 64 years old (23.6\%) and particularly the elderly $(17.7 \%)$. Given the similar poverty rates of the children and the elderly, the difference in their poverty intensities reveals a less difficult situation of the latter.

The difference between the poverty incidence and intensity of the elderly is a clear indication of the need to complement the analysis of the former with the latter. The elderly have long been identified as one of the groups of the Portuguese population with highest poverty incidence. They have been the focus of social policies, such as Minimum and Social Pensions and, recently, the Solidarity Supplement for the Elderly ${ }^{9}$, that have clearly worked in decreasing their poverty intensity.

The situation was more similar in terms of deprivation: $24.8 \%$ of the children and $27.8 \%$ of the elderly were deprived, compared to $21.1 \%$ of the rest of the population. The deprivation intensity was virtually unaffected.

By household type, $38.9 \%$ of the households of 'Single parents with children' were poor, followed by 'Single aged $\geq 65$ ' (34.5\%) and 'Two adults with $3+$ children' (31.9\%). The lowest poverty incidence was in households of 'Three+ adults' (7.6\%). The highest intensities were recorded for 'Single aged $<65$ ' $(37.0 \%)$ and 'Two adults with $3+$ children' $(36.4 \%)$, and the lowest for 'Two adults at least one 65+' (15.7\%).

The highest deprivation rate was recorded for 'Single parents with children': $46.9 \%$ of them were deprived. Living alone was also an important factor: $35.4 \%$ of those 'Single aged $<65$ ' and $37.9 \%$ 
of those 'Single aged $\geq 65$ ' were deprived. The former recorded the highest deprivation intensity (4.2 items). The least deprived were 'Two adults with 2 children' (16.7\%), followed by 'Three+ adults' (18.9\%), who also recorded the lowest deprivation intensity (3.4 items).

The economic status of the population aged 16 and above was also an important factor: those at work recorded the lowest poverty $(12.3 \%)$ and deprivation rates $(17.8 \%)$, followed by those retired (19.7\% and $26.4 \%$, respectively). About $30 \%$ of both unemployed and inactive groups were poor. The intensity of poverty was highest for the unemployed $(27.5 \%)$, but being at work still meant a high value of $21.7 \%$. The unemployed also recorded the highest deprivation rate (38.4\%) and intensity (3.9 items).

Finally, by level of urbanisation, those living in densely populated areas had lower poverty rate (13.4\%) whereas the intermediate and thinly populated areas recorded similarly higher results (just above $22 \%$ ), all with high intensities. The situation changed completely in terms of deprivation: $19.5 \%$ of the individuals living in thinly populated areas were deprived compared to $24.9 \%$ and $22.8 \%$ of those living in densely or intermediate populated areas, respectively.

To summarise, single parent with dependent children, couples with three or more dependent children, single persons, unemployed, other inactive person and children were the more vulnerable categories of the population as they tended to have the highest poverty and deprivation rates and intensities. Households with $3+$ adults, two adults with one dependent child and those at work were the categories 'better off' with the lowest rates and intensities.

Furthermore, if all individuals living in households with children were selected, they represented $60.4 \%$ of the total number of poor, though they were only $54.4 \%$ of the whole population, emphasising the connection between households with children and poverty. However, these households represented $53.1 \%$ of the total of deprived individuals, very close to their national proportion, and suggesting an 'average' incidence of deprivation.

Having identified and characterised the Portuguese who were poor and/or deprived, it is possible to study in the next section those of them who were most vulnerable and socially excluded: the consistent poor.

4. Consistent Poor

The consistent poor, i.e., those individuals who were both poor and materially deprived, represented $8.5 \%$ of the Portuguese population (Table 4 above). Their deprivation levels by item (Table 9) show the same relative ordering as for (all) poor, but with much higher percentages. The highest increases were in TV and meal (2.3 and 2.2 times more than the poor, respectively) and the least in one week holiday away from home (1.1). The most deprived item, holiday, was lacked by an alarming $99.6 \%$ of the consistent poor. They were 6 times more deprived of washingmachine than the whole population and 10.7 than the not poor. They were 7.6 times more deprived of meal than the not poor.

Table 9 - Deprivation Indicators (Consistent Poor)

\begin{tabular}{lcccc} 
& Cons. Poor & Poor & Deprived & All \\
\hline $\begin{array}{l}\text { I1. Inability to face unexpected financial expenses } \\
\text { I2. Inability to afford paying for one week annual holiday }\end{array}$ & 92.6 & 46.7 & 83.7 & 26.2 \\
$\quad$ away from home & 92.1 & 98.2 & 64.3 \\
$\begin{array}{l}\text { I3. Arrears (mortgage or rent payments, utility bills or } \\
\text { hire purchase) }\end{array}$ & 25.2 & 13.2 & 21.1 & 6.5 \\
\hline
\end{tabular}




\begin{tabular}{lcccc} 
& Cons. Poor & Poor & Deprived & All \\
\hline $\begin{array}{l}\text { 14. Inability to afford a meal with meat, chicken or fish } \\
\text { every second day }\end{array}$ & 21.3 & 9.8 & 15.6 & 4.0 \\
15. Inability to keep home adequately warm & 85.0 & 55.8 & 82.9 & 34.9 \\
16. Enforced lack of a washing machine & 15.0 & 7.0 & 10.4 & 2.5 \\
17. Enforced lack of a colour TV & 1.8 & 0.8 & 1.7 & 0.5 \\
18. Enforced lack of a telephone & 15.7 & 8.5 & 16.4 & 4.5 \\
19. Enforced lack of a personal car & 37.9 & 20.2 & 33.9 & 9.4 \\
\hline
\end{tabular}

Source: 2008 Portuguese EU-SILC

The incidence and intensity of those in poverty and deprivation by categories are given in Table 10 and reveal a much bleaker situation. By age group, $12.0 \%$ of the elderly and $10.9 \%$ of the children were consistently poor, the same as just above a quarter (25.4\%) of 'Single parents with children' and $22.7 \%$ of 'Two adults with 3+ children'. Children were the age group with highest poverty intensity (34.2\%), and households with many children (two and three or more) recorded the second highest poverty intensities (36\%).

Living alone was again an important factor: $20.8 \%$ of 'Single aged $\geq 65$ ' and $15.0 \%$ of 'Single aged $<65$ ' were consistently poor, recording poverty intensities of, respectively, $26.1 \%$ and $40.0 \%$. The latter was the highest recorded poverty intensity and was coupled with the highest deprivation intensity (4.4 items).

Even those at work were affected: $4.3 \%$ of them were consistently poor, recording an intensity of poverty of $22.8 \%$ and of deprivation of 3.7 items. The situation of the unemployed was much worse, with $17.8 \%$ of them consistently poor and intensities of $31.3 \%$ and 4.2 items.

The rate of consistently poor of the elderly is $12.0 \%$. However, they have lowest poverty and deprivation intensities, in line with the results of those 'in retirement'.

By area, the differences were not very substantial, though those living in intermediate areas were less likely to be poor (7.9\%), but with higher intensities (31.2\% and 4.0$)$ than those living in thinly $(9.7 \%, 26.2 \%$ and 3.7 , respectively) and densely populated areas (8.3\%, $23.4 \%$ and 3.8$)$.

Once again, households with $3+$ adults, two adults with one dependent child and those at work were the categories presents lower levels of consistent poverty and lower poverty and deprivation intensities.

All these consistent poor households lived in very difficult conditions, but, in particular, $55.7 \%$ of all consistently poor individuals lived in households with children and $14.0 \%$ lived alone.

In all calculations of measures of deprivation so far, all items have been considered equally essential, i.e., have been given the same relative importance or weight. However, it can be argued that the relative importance to the individuals of lacking or being deprived of a week of holidays away from home or of having a good meal every other day or a washing machine are very different. In the next section a weighted measure of deprivation will be calculated and discussed. 


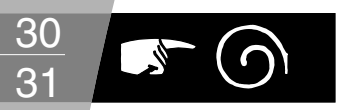

Table 10 - Consistent Poverty

\begin{tabular}{|c|c|c|c|}
\hline & $\begin{array}{c}\text { Consistent } \\
\text { Poverty }\end{array}$ & $\begin{array}{l}\text { Poverty } \\
\text { Intensity }\end{array}$ & $\begin{array}{c}\text { Deprivation } \\
\text { Intensity }\end{array}$ \\
\hline \multicolumn{4}{|l|}{ Gender } \\
\hline Men & 8.0 & 24.2 & 3.9 \\
\hline Women & 9.0 & 27.1 & 3.8 \\
\hline \multicolumn{4}{|l|}{ Age Group } \\
\hline Age $<=17$ & 10.9 & 34.2 & 3.9 \\
\hline $18<=$ Age $<=64$ & 6.8 & 27.5 & 3.9 \\
\hline Age $>=65$ & 12.0 & 18.4 & 3.6 \\
\hline \multicolumn{4}{|l|}{ Household Type } \\
\hline Single - age $<65$ & 15.0 & 40.0 & 4.4 \\
\hline Single - age $>=65$ & 20.8 & 26.1 & 3.7 \\
\hline Two adults younger than 65 years & 7.9 & 26.4 & 3.9 \\
\hline Two adults, at least one aged 65 years and over & 10.4 & 17.2 & 3.8 \\
\hline Three or more adults & 3.6 & 19.5 & 3.3 \\
\hline Single parent with dependent children & 25.4 & 31.3 & 3.8 \\
\hline Two adults with one dependent child & 6.6 & 18.7 & 3.7 \\
\hline Two adults with two dependent children & 6.6 & 36.3 & 3.9 \\
\hline Two adults with three + dependent children & 22.7 & 36.4 & 4.0 \\
\hline Other Households with dependent children & 6.9 & 22.3 & 4.0 \\
\hline \multicolumn{4}{|l|}{ Economic Status } \\
\hline Working & 4.3 & 22.8 & 3.7 \\
\hline Unemployed & 17.8 & 31.3 & 4.2 \\
\hline In retirement & 10.6 & 18.6 & 3.6 \\
\hline Other inactive person & 14.4 & 28.4 & 4.0 \\
\hline \multicolumn{4}{|l|}{ Degree of Urbanisation } \\
\hline densely populated area & 8.3 & 23.4 & 3.8 \\
\hline intermediate area & 7.9 & 31.2 & 4.0 \\
\hline thinly populated area & 9.7 & 26.3 & 3.7 \\
\hline Total & 8.5 & 26.2 & 3.8 \\
\hline
\end{tabular}

Source: 2008 Portuguese EU-SILC 


\section{Material Deprivation versus Weighted Material Deprivation}

There is a growing body of literature that addresses the issue of weighted deprivation: should all items be considered equally important, how and who should decide their relative importance, how can this information be incorporated in the analysis and what is its impact in each country and across the EU.

A measure of the intensity of deprivation $u_{i}$ of individual $i(i=1,2, \ldots, n)$ can be written as:

$$
u_{i}=\sum_{j=1}^{m} w_{j} x_{i j}
$$

where $x_{i j}$ is the non-negative level of deprivation of individual $i$ on item $j(j=1,2, \ldots, m)$ and is equal to either 0 (individual possesses the item) or 1 (lacks it) and all weights, $w_{j}$, are normalised to sum one. So far, all weights were considered to be the same and equal to 1 . Therefore, the measure of deprivation intensity used in the previous sections was a simple count of the number of items individual $i$ was deprived of, aggregated over the whole population, and using a threshold of $3+$ items to define deprivation. Although there are advantages to this method, such as simplicity of calculations and interpretation of the results, no meddling by the researcher or need of extra information, its advantages can become drawbacks as, for example, it implies equal importance and substitutability between the items.

An improvement to the methodology is to consider the possibility of weighting each item differently in order to reflect the different impact of its enforced lack on the standard of living of the individuals. The ratio of each pair of weights can then be seen as a substitution rate between the two items they refer to. Different methods of weighting have been suggested and discussed in the literature ${ }^{10}$.

Decqanc and Lugo (2010) discuss the relative merits of different types of weights such as: data driven weights (like prevalence weights ${ }^{11}$ ), normative weights (like equal weights or arbitrarily set weights), and hybrids (like survey based weights). The latter have a strong advantage over the other two types of weights because they avoid the argument between the 'is' and 'ought to be' methods: survey based, or consensus, weights are «based directly on the opinions of a representative group of individuals in the society". They are (exogenous) weights based on the social perception of the importance of each item for the achievement of a minimum standard of living.

The option in this paper for the consensus weighting method is made possible by the existence of the Eurobarometer survey of 2007 on «Poverty and Exclusion». This survey was done in all EU countries to support the choice of deprivation items included in the EU-SILC. The Portuguese results of the survey relevant to the 9 items are summarised in Table 11.

10. For a general discussion on weights see, for example, Decanq and Lugo (2010), and for applications Guio et al. (2009) and Bossert et al. (2009).

11. Prevalence weighting is an endogenous, frequency based method: the weight of each item is calculated from the data as the normalised percentage of the individuals that possess that item. It rests on the assumption that the most possessed item is the most valued by the individuals, and therefore an individual who does not possess it will feel most deprived of (subjective perception of deprivation). In this case, the weights were calculated from column 4 (All) of Table 7. The normalised weights of the 9 items varied between 0.0724 for holiday (the least possessed item) and 0.1246 for TV (the most possessed). By construction, these weights will vary every year, and may therefore introduce extra variability in the analysis. 
Table 11 - Eurobarometer answers - Portuguese results (in row \%)

\begin{tabular}{lccccc} 
Ability to have: & $\begin{array}{c}\text { Absolutely } \\
\text { necessary }\end{array}$ & Necessary & $\begin{array}{c}\text { Desirable, } \\
\text { but not } \\
\text { necessary }\end{array}$ & $\begin{array}{c}\text { Not at all } \\
\text { necessary }\end{array}$ & $\begin{array}{c}\text { Deprivation } \\
\% \text { (total } \\
\text { population) }\end{array}$ \\
\hline Expenses & 45 & 38 & 16 & 0 & 26.2 \\
Holiday & 17 & 44 & 32 & 7 & 64.3 \\
Arrears & 70 & 26 & 3 & 0 & 6.5 \\
Meal & 76 & 22 & 2 & 0 & 4.0 \\
Home warm & 59 & 37 & 4 & 0 & 34.9 \\
Washing machine & 65 & 30 & 4 & 1 & 2.5 \\
TV & 35 & 52 & 12 & 1 & 0.5 \\
Phone & 17 & 41 & 29 & 14 & 4.5 \\
Car & 29 & 38 & 27 & 6 & 9.4 \\
\hline Total & 413 & 328 & 129 & 29 & - \\
\hline
\end{tabular}

Source: several tables in the Appendix of Eurobarometer 279 «Poverty and Exclusion» and Table 6 (last column).

As in Bossert et al. (2009) and Guio (2009), the weights were calculated as the normalised proportions of the 'absolutely necessary' answers ( $2^{\text {nd }}$ column of Table 11), as these were the proportions by which each item was considered essential for a "decent standard of living" ${ }^{12}$ It is immediately noticeable that the most deprived item, holiday, was considered the least essential (together with phone): only $17 \%$ of the Portuguese respondents considered it absolutely necessary. Of the items the respondents considered most essential: meal (76\%), arrears (70\%) and washing machine (65\%), only $4.0 \%, 6.5 \%$ and $2.5 \%$ of the Portuguese population were deprived of, respectively. Perhaps not by coincidence, washing machine, meal and arrears were the items that the consistent poor were found to be lacking much more than the not poor in the previous section.

It is necessary to define the threshold of material deprivation: when and how is an individual considered to be deprived? The definition of deprivation moves from a simple count of items to the normalised weighted sum of items. Therefore, an individual deprived of holiday, phone and car (the least weighted items, adding to 0.1526 ) will be considered less deprived than an individual deprived of either one (or one only) of the most valued: meal $(0.1840)$ or arrears $(0.1695)$. It is not the number of items, but their relative (weighted) consensual social importance that defines deprivation.

Guio (2009) argues that the threshold should be chosen as the sum of the two highest weights (here equal to 0.3535 ) so that an individual could lack more than two (lower weighted) items and not be deprived, but could not lack the two highest weighted items plus any other item and not be deprived. In other words, the sum of the two highest weights acts as a lower bound of the previous $3+$ threshold as it is the upper bound of being deprived of exactly two items. This definition of weighted material deprivation and threshold will be used in the next section to analyse the Portuguese data. 


\section{Weighted Material Deprivation}

In this section the concept of weighted material deprivation is used and the results compared with those obtained using the concept of material deprivation. As discussed above, the consensus weights were calculated from the 'absolutely necessary' answers of the Eurobarometer survey, and the threshold is defined as the sum of the two highest weights.

The impact of the definition of weighted deprivation (hereafter wdeprivation) is evident in Table 12: the wdeprivation rate is equal to $9.8 \%$. Comparing with Table $3,13.1 \%$ of that population, almost 1.4 million individuals that were materially deprived are no longer considered (weighted) deprived. This result is mainly a consequence of the reclassification of almost $9.2 \%$ of the population from being 'not poor and deprived' to being 'neither poor nor deprived'. ${ }^{13}$

\section{Table 12 - Material Deprivation (weighted)}

\begin{tabular}{cccc} 
& Value & \multicolumn{2}{c}{$95 \%$ Confidence Interval } \\
\cline { 3 - 4 } & & Lower & Upper \\
\hline Deprivation Incidence & 9.8 & 8.2 & 11.5 \\
Deprivation Intensity & $(0.8)$ & & 0.5 \\
& 0.5 & 0.5 & \\
& $(0.0)$ &
\end{tabular}

Notes: Standard errors in parenthesis. Source: 2008 Portuguese EU-SILC

The category of 'not poor and deprived' shrunk from $14.5 \%$ of the population to $5.3 \%$ (Table 13 ), a result that seems more reasonable. The inverse happened to the 'poor and not deprived', which increased by over 400 thousand individuals ( $4.0 \%$ of the population) from the consistent poor, which became $4.5 \%$ of the population.

Table 13 - Monetary Poverty versus Weighted Material Deprivation

\begin{tabular}{lccc} 
& Not Deprived & Deprived & Total \\
\hline Not Poor & 76.1 & 5.3 & 81.5 \\
& $(1.1)$ & $(0.6)$ & $(0.9)$ \\
Poor & 14.0 & 4.5 & 18.5 \\
& $(0.8)$ & $(0.5)$ & $(0.9)$ \\
\hline Total & 90.2 & 9.8 & 100.0
\end{tabular}

Notes: Standard errors in parenthesis. Source: 2008 Portuguese EU-SILC

Fewer of the high income individuals were considered deprived (Table 14): around $3 \%$ of the individuals in any decile above the $5^{\text {th }}$ were deprived, a much lower percentage than in Table 6 discussed before. Nevertheless, $0.7 \%$ of the individuals in the highest decile were still deprived. 
The results of wdeprivation so far point to a marked decrease in the number of individuals that, though not poor, were considered deprived, particularly those in high deciles of the income distribution. This alteration is due to the fact that to be wdeprived, one needs to be deprived of really essential items, and not solely of whichever three.

\section{Table 14 - Weighted Material Deprivation by equivalent income decile}

\begin{tabular}{lcc} 
& Deprivation Incidence & Deprivation Index \\
\hline $1^{\text {st }}$ decile & 29.8 & 0.2559 \\
$2^{\text {nd }}$ decile & 17.1 & 0.2154 \\
$3^{\text {rd }}$ decile & 16.8 & 0.1977 \\
$4^{\text {rd }}$ decile & 12.2 & 0.1649 \\
$5^{\text {th }}$ decile & 6.8 & 0.1477 \\
$6^{\text {th }}$ decile & 5.3 & 0.1180 \\
$7^{\text {th }}$ decile & 6.1 & 0.1129 \\
$8^{\text {th }}$ decile & 2.8 & 0.0806 \\
$9^{\text {th }}$ decile & 0.8 & 0.0485 \\
$1^{\text {th }}$ decile & 0.7 & 0.0191 \\
\hline Total & 9.8 & 0.1360
\end{tabular}

Source: 2008 Portuguese EU-SILC

These results are confirmed in Table 15, where the percentages of individuals who were wdeprived by each item are compared to the national percentages.

\section{Table 15 - Weighted Deprivation Indicators (Consistent Poor)}

\begin{tabular}{lcccc} 
& Cons. Poor & Poor & Deprived & All \\
\hline $\begin{array}{l}\text { 11. Inability to face unexpected financial expenses } \\
\begin{array}{l}\text { I2. Inability to afford paying for one week annual } \\
\text { holiday away from home }\end{array}\end{array}$ & 86.9 & 46.7 & 86.9 & 26.2 \\
$\begin{array}{l}\text { I3. Arrears (mortgage or rent payments, utility bills } \\
\quad \text { or hire purchase) }\end{array}$ & 37.1 & 13.2 & 37.8 & 6.5 \\
$\begin{array}{l}\text { 14. Inability to afford a meal with meat, chicken or fish } \\
\quad \text { every second day }\end{array}$ & 38.7 & 9.8 & 34.8 & 4.0 \\
$\begin{array}{l}\text { 15. Inability to keep home adequately warm } \\
\text { 16. Enforced lack of a washing machine }\end{array}$ & 94.1 & 55.8 & 89.3 & 34.9 \\
$\begin{array}{l}\text { 17. Enforced lack of a colour TV } \\
\text { I8. Enforced lack of a telephone }\end{array}$ & 23.0 & 7.0 & 18.4 & 2.5 \\
19. Enforced lack of a personal car & 20.7 & 0.8 & 3.4 & 0.5 \\
\hline
\end{tabular}


There was a noticeable increase in the percentage of the deprived individuals that were deprived of each item, particularly in the three highest items (holiday, homewarm and expenses). There was also a much more significant increase in the deprivation rates of the items considered most essential (meal and washingmachine). This is a consequence of the weighting: to be deprived the individuals have to be deprived of the more basic items which are socially perceived to be essential or to be deprived of many more of the less weighted items.

Another consequence of the weighting deprivation definition is that there was much less difference in the indicators of Table 15 between (all) the deprived and the consistent poor (deprived who were also poor).

Table 16 - Monetary poverty versus Weighted Material Deprivation

$\begin{array}{cccc}\begin{array}{c}\text { Poverty } \\ \text { Incidence }\end{array} & \begin{array}{c}\text { Poverty } \\ \text { Intensity }\end{array} & \begin{array}{c}\text { Deprivation } \\ \text { Incidence }\end{array} & \begin{array}{c}\text { Deprivation } \\ \text { Intensity }\end{array}\end{array}$

\begin{tabular}{|c|c|c|c|c|}
\hline \multicolumn{5}{|l|}{ Gender } \\
\hline Men & 17.9 & 22.5 & 9.5 & 0.4663 \\
\hline Women & 19.1 & 23.6 & 10.2 & 0.4689 \\
\hline \multicolumn{5}{|l|}{ Age Group } \\
\hline Age $<=17$ & 22.8 & 26.2 & 12.2 & 0.4686 \\
\hline $18<=$ Age $<=64$ & 16.3 & 23.6 & 9.0 & 0.4646 \\
\hline Age $>=65$ & 22.3 & 17.7 & 10.3 & 0.4766 \\
\hline \multicolumn{5}{|l|}{ Household Type } \\
\hline Single - age $<65$ & 25.0 & 37.0 & 21.3 & 0.4883 \\
\hline Single - age $>=65$ & 34.5 & 26.9 & 13.9 & 0.4947 \\
\hline Two adults younger than 65 years & 16.5 & 23.6 & 8.8 & 0.4721 \\
\hline Two adults, at least one aged 65 years and over & 21.7 & 15.7 & 11.0 & 0.4755 \\
\hline Three or more adults & 7.6 & 18.8 & 5.7 & 0.4328 \\
\hline Single parent with dependent children & 38.9 & 31.3 & 24.9 & 0.4364 \\
\hline Two adults with one dependent child & 17.0 & 18.7 & 7.7 & 0.4744 \\
\hline Two adults with two dependent children & 20.6 & 24.8 & 6.1 & 0.4994 \\
\hline Two adults with three + dependent children & 31.9 & 36.4 & 23.1 & 0.4593 \\
\hline Other Households with dependent children & 18.2 & 22.9 & 12.0 & 0.4610 \\
\hline \multicolumn{5}{|l|}{ Economic Status } \\
\hline Working & 12.3 & 21.7 & 7.1 & 0.4532 \\
\hline Unemployed & 29.3 & 27.5 & 21.2 & 0.4870 \\
\hline In retirement & 19.7 & 18.1 & 10.1 & 0.4672 \\
\hline Other inactive person & 29.5 & 25.5 & 12.0 & 0.4876 \\
\hline \multicolumn{5}{|l|}{ Degree of Urbanisation } \\
\hline densely populated area & 13.4 & 23.4 & 11.6 & 0.4613 \\
\hline intermediate area & 22.2 & 22.4 & 9.0 & 0.4802 \\
\hline thinly populated area & 23.4 & 23.5 & 7.7 & 0.4665 \\
\hline Total & 18.5 & 23.2 & 9.8 & 0.4677 \\
\hline
\end{tabular}


Analysing the wdeprived by categories (Table 16) shows the general decrease in the number of deprived. However, by age group this reduction was relatively smaller for the children $(12.2 \%$ of them were wdeprived) particularly versus the elderly (10.3\%) which were the more deprived age group. By household type, almost a quarter of the single parents were deprived (24.9\%), followed by 'Two adults with $3+$ children' $(23.1 \%)$ and 'Single $<65$ ' $(21.3 \%)$. The percentage of all other households that were deprived was below $14 \%$, much lower than the above.

\section{Table 17 - Weighted Consistent Poverty}

$\begin{array}{ccc}\begin{array}{c}\text { Consistent } \\ \text { Poverty }\end{array} & \begin{array}{c}\text { Poverty } \\ \text { Intensity }\end{array} & \begin{array}{c}\text { Deprivation } \\ \text { Intensity }\end{array}\end{array}$

\begin{tabular}{lccc}
\hline Gender & & & \\
$\quad$ Men & 4.3 & 30.2 & 0.4848 \\
Women & 4.7 & 28.4 & 0.4901 \\
\hline Age Group & & & \\
$\quad$ Age $<=17$ & 6.7 & 36.4 & 0.4749 \\
18<= Age <=64 & 3.7 & 29.5 & 0.4918 \\
Age >= 65 & 4.9 & 18.8 & 0.4945 \\
\hline Household Type & & & \\
Single - age <65 & 10.3 & 40.0 & 0.5094 \\
Single - age >=65 & 8.5 & 25.9 & 0.4861 \\
Two adults younger than 65 years & 4.5 & 21.4 & 0.5140 \\
Two adults, at least one aged 65 years and over & 4.7 & 18.6 & 0.5118 \\
Three or more adults & 1.0 & 14.7 & 0.4307 \\
Single parent with dependent children & 14.4 & 38.4 & 0.4464 \\
Two adults with one dependent child & 3.1 & 20.4 & 0.4665 \\
Two adults with two dependent children & 3.5 & 40.6 & 0.4867 \\
Two adults with three + dependent children & 17.1 & 44.9 & 0.4615 \\
Other Households with dependent children & 4.3 & 34.2 & 0.5252 \\
\hline Economic Status & & & \\
Working & 2.2 & 23.6 & 0.4721 \\
Unemployed & 12.2 & 34.2 & 0.4999 \\
In retirement & 4.4 & 18.6 & 0.4852 \\
Other inactive person & 7.6 & 32.4 & 0.5174 \\
\hline Degree of Urbanisation & & & \\
densely populated area & 4.5 & 29.5 & 0.4838 \\
intermediate area & 4.4 & 30.2 & 0.5087 \\
thinly populated area & 4.5 & 27.1 & 0.4678 \\
\hline Total & 4.5 & 29.8 & 0.4876 \\
\hline
\end{tabular}


The elderly seem to have done relatively better with $10.3 \%$ of them wdeprived and $10.1 \%$ of those in retirement. This percentage is well below that of the unemployed $(21.2 \%)$ and is closer to those at work $(7.1 \%)$.

The consistent poor (both poor and wdeprived) represented $4.5 \%$ of the population. By age group, again a higher percentage of children (6.7\%) were consistent poor than any other age group (Table 17$)$. Those at work $(2.2 \%)$ and retired $(4.4 \%)$ were much less likely to be consistently poor than the unemployed (12.2\%). The tendencies detected for the wdeprived were much replicated for the consistent poor, suggesting a closer relation than before between the two groups. The level of urbanisation had little impact in the poverty rate, but again showed that those living in intermediate areas had higher poverty and deprivation intensities.

The stronger incidence of poverty and deprivation on households with children detected earlier is also felt: $62.0 \%$ of all consistent poor lived in households with children when they represented only $54.4 \%$ of the whole population.

Wdeprivation seems to give interesting results in the reduction of the number of individuals who were not poor and deprived (identifying them as not poor and not deprived instead) and in identifying the individuals who were truly deprived of the essential items. This contributes to the large reduction in the deprivation rate.

However, the method also, but in much smaller degree, reduces the number of poor who were deprived (consistent poor). As the answers the latter gave to the 'lack of item' questions follow very much the same pattern as the other groups of society, even giving more weight to the essential items they are more likely to be deprived of is not enough for the method to give results that would 'reinforce' the number of consistent poor. Only $24.3 \%$ of the poor were wdeprived and only $45.8 \%$ of the wdeprived were poor. It is not possible for the method to overcome the fact that, from the answers they gave to the questions, they perhaps did not perceive themselves to be deprived of those items or had no such expectations or simply had what they considered access to them (the elderly had virtually no arrears, for example).

\section{Conclusions}

In this paper, though still in a preliminary form, we analysed the implication of the simultaneous use of monetary poverty and material deprivation indicators to characterise the most vulnerable individuals and households in Portugal.

Townsend's (1979) broader concept of poverty was used: it is based on the exclusion of the individuals from the regular standard of living of the society they live in due to the lack of monetary and non-monetary resources. This definition allows for a more detailed characterisation of who the poor are and of the depth of their poverty. The joint analysis of the incidence and intensity of both monetary poverty and material deprivation allows for a more rigorous identification of poverty in Portugal.

The information available in EU-SILC was used to discuss different methods of combining these two poverty dimensions. We started with the methodology adopted by the EU, but then discussed and evaluated alternative methods of identification and aggregation of the deprivation indicators.

A first conclusion of this study is that using the concept of material deprivation leads to a significantly deeper understanding of what is known about poverty in Portugal and of which sectors of the population are more affected.

A second conclusion is that the methodology used to define and aggregate the deprivation indicators has a strong influence on the results. However, these differences are limited to the levels of poverty and deprivation detected: the identification of the more and less vulnerable groups remains unchanged. A thorough discussion of the methodology used to study this new poverty dimension is clearly necessary. 
The EU methodology for the construction of deprivation indicators is a significant step towards the use of the non-monetary dimensions of poverty at European level. However, it needs to be improved so that the inconsistent groups, particularly the highest income households that show significant levels of deprivation, can be better understood. The fact that about $10 \%$ of the Portuguese households with adult equivalent income above the median were considered to be deprived has to be worrying. Further research is required into their true standards of living.

The consideration of alternative weights for the different dimensions of deprivation based on the Eurobarometer results reduces significantly the number of deprived households and of consistent poor. It can be seen as a way to merge the two poverty dimensions and to identify situations of extreme poverty.

Three social groups were found to be particularly vulnerable, whatever methodology: single parent households, extended households with children, and the unemployed. These groups combine high levels of incidence and intensity of both monetary poverty and material deprivation. Therefore they are the sectors of the population where consistent poverty is most prevalent.

The analysis of the different poverty dimensions by age group is particularly enlightening. Although the children and the elderly record higher poverty and deprivation rates than the rest of the population, their relative situation is significantly different in terms of poverty intensity, especially monetary poverty. As a result of existing different social policies specifically targeted at the elderly population, the monetary poverty intensity of this age group is lower than that of the rest of the population, and their material deprivation is virtually equal to the national average. It is then very revealing that when the analysis switched from the usage of the EU (non-weighted) deprivation indicators to the weighted indicators, the elderly consistent poverty rate was significantly reduced. The same result does not occur in the children's age group, particularly in the case of children that live in single parent or large households, where high poverty and deprivation rates are always combined with high intensity rates and levels of consistent poverty.

The analysis of both monetary and material poverty by age group, together with the identification of the three most vulnerable social groups identified above, reveals children's poverty as one of the most worrying features of Portuguese society.

Last, but not least, a note on the scope and depth of the analysis of deprivation in this paper. Although different methodologies of construction and aggregation of the deprivation indicators were discussed and implemented, the analysis was restricted to the nine items selected by the EU methodology. Further and more thorough discussion of deprivation indicators must include a discussion on whether the nine indicators selected are the most adequate to achieve a meaningful analysis of deprivation in Portugal and in Europe. 
Atkinson, A. (2003), Multidimensional Deprivation: Contrasting Social Welfare and Counting Approaches, Journal of Economic Inequality, 1-1, 51-65.

Bossert, W. et al. (2009), Multidimensional Poverty and Material Deprivation, ECINEQ Working Paper, 2009-129.

Decancq, K.; Lugo, M.A. (2010) Weights in Multidimensional Indices of Well Being: An Overview, CES Discussion paper, 10.06 .

Foster, J. et al. (1984), A Class of Decomposable Poverty Measures, Econometrica; 52(3), 761-66.

Guio, A.C. (2009), What can be learned from deprivation indicators in Europe?, Luxembourg, Eurostat.

Guio, A.C. et al. (2009), A European Union Approach to Material Deprivation using EU-SILC and Eurobarometer Data, IRISS Working Paper 2009-19.

Guio, A.C. (2005), Material Deprivation in the EU, Statistics in Focus, Population and Social Conditions, Living Conditions and Welfare, 21/2005, Eurostat, Luxembourg.

Ringen, S. (1988), Direct and Indirect Measures of Poverty, Journal of Social Policy, 17, 351-366.

Rodrigues, C.F. (2010), Outros Olhares sobre os Indicadores de Pobreza, in INE(Ed) About poverty, inequality and material deprivation in Portugal, Lisboa, INE, pp. 115-125.

Whelan, C. T. et al. (2008), Measuring Material Deprivation in the Enlarged EU, Economic and Social Research Institute (ESRI), Working Paper 249.

Townsend, P. (1979), Poverty in the United Kingdom, Penguin, Harmondsworth.

TNS Opinion \& Social (2007), Poverty and Exclusion, Report on the Special Euro-barometer N279/Wave 67.1.

Available at: http://ec.europa.eu/public_opinion/archives/ebs/ebs_279.pdf 